\title{
Utility of thiocarbamoyl moiety in synthesis of some new sulphur containing heterocyclic compounds and evaluation of their antimicrobial activity
}

\author{
Ahmed Fadda a,*, Hala Refat b and Shimaa Kamal a \\ a Department of Chemistry, Faculty of Science, Mansoura University, 35516 Mansoura, Egypt. \\ b Department of Chemistry, Faculty of Education, Suez Canal University, 35516 Al-Arish, Egypt \\ *Corresponding author at: Department of Chemistry, Faculty of Science, Mansoura University, 35516 Mansoura, Egypt. \\ Tel.: +2.050.2218521. Fax: +2.050.2246781. E-mail address: afadda50@yahoo.com (A. Fadda).
}

\section{ARTICLE INFORMATION}

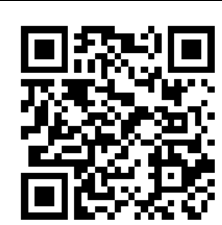

DOI: $10.5155 /$ eurjchem.5.2.296-304.1001

Received: 09 December 2013

Received in revised form: 08 January 2014

Accepted: 28 January 2014

Online: 30 June 2014

\section{KEYWORDS}

\section{Thiazoles}

Thiophene

Thiocarbamoyl

Antimicrobial activity

Cyclic dithio compounds

N,N'-(1,4-Phenylene)bis(2-cyanoacetamide)

\section{Introduction}

Aryl isothiocyanates are versatile reagents that have been used as synthetic intermediates to prepare biologically active heterocyclic compounds [1]. The diversity of biological and physiological activities of several organic sulfur heterocycles may be attributed to the presence of the $\mathrm{N}=\mathrm{C}=\mathrm{S}$ fragment, characteristic of thiazoles, thiazolines and thiazolidines [2]. These are known to exhibit pesticidal [3], anticonvulsant [4], nematocidal [5], herbicidal [6], antiviral [7], fungicidal [8], bactericidal $[9,10]$, antiprotozal [11], and hypoglycemic activity [12]. They are also act as chemotherapeutic agents. This encouraged us to design a specific program aimed at the synthesis of several new derivatives of these ring systems.

The present work outlines the chemistry of thiocarbamoyl derivatives not all but the most important in the synthesis of heterocyclic compounds. The vast majority of thiocarbamoyl derivatives have been the subject of many studies, for the preparation of potentially biologically active compounds and for some industrial uses [13-15]. In this work, the utility of the title compounds in heterocyclic synthesis has been studied.

We have been particularly interested to study if reactions of such thiocarbamoyl might be extended to include a more general synthesis of other classes of organic compounds and its utility as synthetic intermediate for the synthesis of new heterocyclic compounds. The present work, reports on the synthesis of several new thiazole and thiophene derivatives by the reaction of thiocarbamoyl of the type $\mathbf{3}$ with compounds containing an active methylene group in the presence of a base. Reactions of this type have not been reported previously, but were found to give products in excellent yields under very mild conditions.

Moreover, in continuation of the previously reported work $[16,17]$ the resulting thiazole and thiophene derivatives have latent functional substituents, which have potential for further chemical transformations and new routes for the preparation of substituted thiazole and thiophene derivatives. Now, we have extended our synthetic program to the synthesis of otherwise inaccessible heterocyclic ring system, utilizing phenyl isothiocyanate as a key starting material. It is known that a great variety of reactants bearing the $\mathrm{N}=\mathrm{C}=\mathrm{S}$ fragment undergo cyclization on reaction with $\alpha$-halocarbonyl compounds to afford thiophenes [18-22], thiazoles, 2,3-dihydro thiazoles [4], which have been shown to exhibit antiprotozoal [11], and fungicidal properties [8].

\section{Experimental}

\subsection{Instrumentation}

All melting points are recorded on Gallenkamp electric melting point apparatus and are uncorrected. 

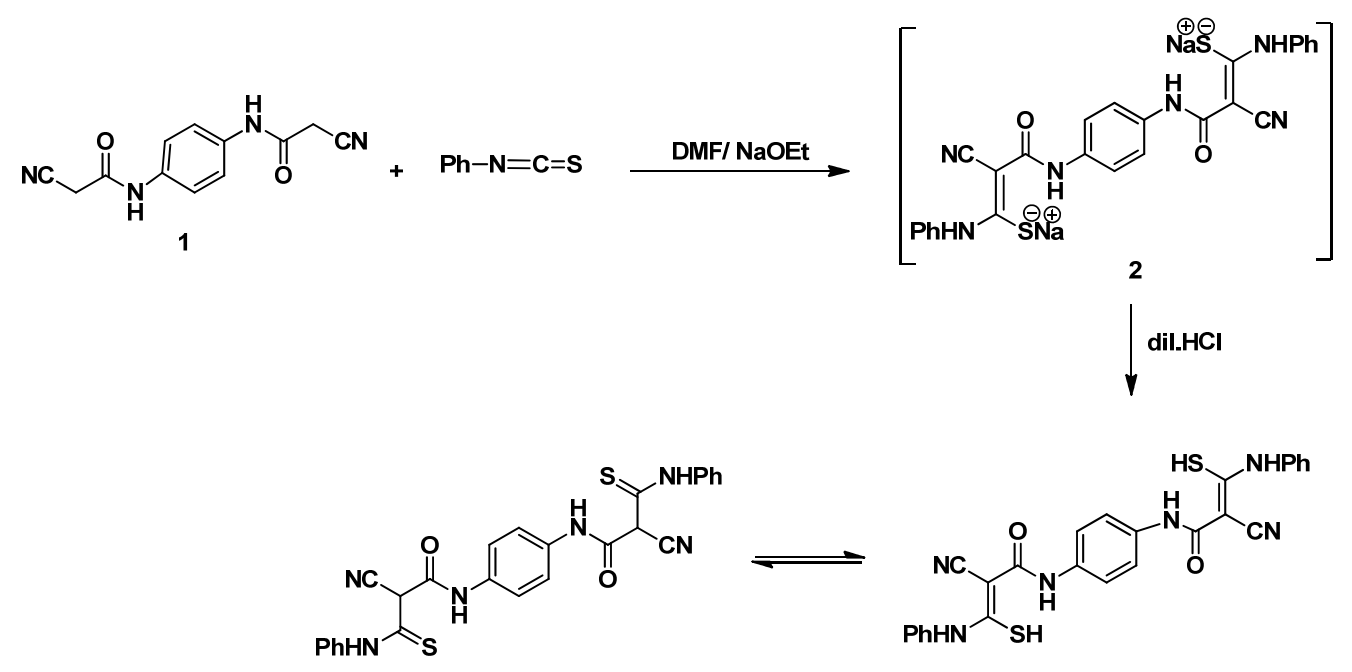

3

Scheme 1

The IR spectra $(\mathrm{KBr})$ were recorded on Perkin Elmer Infrared Spectrophotometer Model 157, Grating. The ${ }^{1} \mathrm{H}$ and ${ }^{13} \mathrm{C}$ NMR spectra were run on Varian Spectrophotometer at 300 and $75 \mathrm{MHz}$, respectively, using tetramethylsilane (TMS) as an internal reference and DMSO- $d_{6}$ as solvent. The mass spectra (EI) were recorded on $70 \mathrm{eV}$ with Kratos MS equipment and/or a Varian MAT 311 A spectrometer. Elemental analyses (C, H and $\mathrm{N}$ ) were carried out at the micro analytical center of Cairo University, Giza, Egypt, the results were found to in good agreement $( \pm 0.3 \%)$ with the calculated values.

\subsection{Synthesis}

\subsubsection{Synthesis of $\left(2 \mathrm{z}, 2^{\prime} \mathrm{z}\right)-\mathrm{N}, N^{\prime}-(1,4-$ phenylene)bis(2-cyano-} 3-mercapto-3-(phenylamino)acrylamide) (3)

To a solution of compound 1 ( $2.4 \mathrm{~g}, 0.01 \mathrm{~mol})$, in DMF (30 $\mathrm{mL})$, and phenyl isothiocyanate $(3 \mathrm{~mL}, 0.02 \mathrm{~mol})$ in presence of $\mathrm{NaOEt}$ (formed from $0.4 \mathrm{~g} \mathrm{Na}+20 \mathrm{~mL}$ EtOH), was stirred overnight at room temperature to give compound $\mathbf{2}$ as nonisolable salt. The reaction mixture was poured onto crushed ice and neutralized by dilute $\mathrm{HCl}$. The obtained solid product was collected by filtration, washed, dried and crystallized from ethanol to give compound 3 (Scheme 1). Color: Green powder. Yield: 90\%. M.p.:198 ${ }^{\circ} \mathrm{C}$. IR ( $\left.\mathrm{KBr}, v, \mathrm{~cm}^{-1}\right): 3291$ (NHCO), 3043 (NHPh), 2185 (CN), 1593 (C=0), 1233 (C=S). ${ }^{1} \mathrm{H}$ NMR (300 MHz, DMSO- $\left.d_{6}, \delta, p p m\right): 3.84(\mathrm{~s}, 2 \mathrm{H},-2 \mathrm{SH}-), 4.25(\mathrm{~s}, 2 \mathrm{H}$, 2NHPh), 7.02-7.78 (m, 14H, Ar-H), 9.75 (s, 2H, 2NHCO). ${ }^{13} \mathrm{C}$ NMR (75 MHz, DMSO- $d_{6}, \delta, \mathrm{ppm}$ ): 171 (2C, C-SH), 161 (2C, CO), 138 (2C, Ar-C), 133 (2C, Ar-C), 131 (2C, Ar-C), 129 (2C, Ar-C), 126 (2C, Ar-C), 124 (2C, Ar-C), 123 (2C, Ar-C), 120 (4C, Ar-C), 118 (2C, CN), 88 (2C, C-CN). LC-MS ( $\mathrm{m} / \mathrm{z}, \%): 512\left(\mathrm{M}^{+}, 58\right), 470$ (58), 462 (56), 349 (96), 333 (42), 273 (47), 226 (87), 206 (100), 200 (89), 174 (33), 136 (17), 115 (48), 94 (56), 65 (43), 52 (26). Anal. calcd. for $\mathrm{C}_{26} \mathrm{H}_{20} \mathrm{~N}_{6} \mathrm{O}_{2} \mathrm{~S}_{2}$ (512.11): C, 60.92; $\mathrm{H}$, 3.93; N, 16.39; 0, 6.24; S, 12.51. Found: C, 60.85; H, 3.90; N, $16.46 ; 0,6.26 ; \mathrm{S}, 12.52 \%$.

\subsubsection{Synthesis of $\left(2 \mathrm{z}, 2^{\prime} \mathrm{z}\right)-\mathrm{N}, N^{\prime}-(1,4-$ phenylene)bis(2-cyano- 2-(3,4-diphenylthiazol-2(3H)-ylidene)acetamide) (4)}

Method A : A solution of compound $3(5.12 \mathrm{~g}, 0.01 \mathrm{~mol})$, in a mixture of EtOH:DMF $(2: 1, v: v)(30 \mathrm{~mL})$, and phenacyl bromide ( $4 \mathrm{~g}, 0.02 \mathrm{~mol}$ ), in presence of triethylamine (4 drops), was refluxed for $4 \mathrm{~h}$. The reaction mixture was allowed to cool, poured onto crushed ice. The obtained solid product was collected by filtration, washed, dried and crystallized from ethanol to give compound 4 (Scheme 2).

Method B: A solution of compound $5(7.48 \mathrm{~g}, 0.01 \mathrm{~mol})$, in DMF $(30 \mathrm{~mL})$, in presence of triethylamine (4 drops), was refluxed $4 \mathrm{~h}$. The reaction mixture was poured onto crushed ice. The obtained solid product was collected by filtration, washed, dried and crystallized from ethanol to give compound 4.

$\left(2 z, 2^{\prime} z\right)-N, N^{\prime}-(1,4-$ phenylene)bis(2-cyano-2-(3,4-diphenyl thiazol-2(3H)-ylidene)acetamide) (4): Color: Brown powder. Yield: 90\%. M.p.: $272{ }^{\circ} \mathrm{C}$. IR ( $\left.\mathrm{KBr} v / \mathrm{cm}^{-1}\right): 3284(\mathrm{NH}), 3054$ $\left(\mathrm{CH}_{2}\right), 2170(\mathrm{CN}), 1581(\mathrm{CONH}), 1552(\mathrm{C}=\mathrm{C}) .{ }^{1} \mathrm{HNMR}(300 \mathrm{MHz}$, DMSO- $\left.d_{6}, \delta, \mathrm{ppm}\right): 6.23\left(\mathrm{~s}, 2 \mathrm{H}, 2 \mathrm{CH}_{\text {thiazole }}\right), 7.23-7.45(\mathrm{~m}, 20 \mathrm{H}$, Ar-H), 7.33-7.46 (dd, 4H, Ar-H AB system), 9.50 (s, 2H, 2NHCO). LC-MS ( $m / z, \%): 712\left(\mathrm{M}^{+}, 2\right), 689$ (2), 454 (2), 428 (5), 368 (7), 343 (5), 319 (8), 294 (95), 276 (24), 217 (24), 134 (31), 77 (100). Anal. calcd. for $\mathrm{C}_{42} \mathrm{H}_{28} \mathrm{~N}_{6} \mathrm{O}_{2} \mathrm{~S}_{2}$ (712.17): C, 70.77; H, 3.96; $\mathrm{N}, 11.79 ; 0,4.49 ; \mathrm{S}, 9.00$. Found: C, 70.69; H, 4.00; N, 11.81; O, $4.50 ; \mathrm{S}, 9.01 \%$.

2.2.3. Synthesis of $(2 Z, 2 ' Z)-N, N$ '-(1,4-phenylene)bis(2-cyano3-((2-oxo-2-phenylethyl)thio)-3-(phenylamino)acrylamide) (5), (2Z,2'Z)- $N, N^{\prime}-(1,4-p h e n y l e n e) b i s(2-c y a n o-3-((c y a n o$ methyl)thio)-3-(phenylamino)acrylamide) (9) and $\left(2 Z, 2^{\prime} Z\right)$ $N, N^{\prime}-(1,4-p h e n y l e n e) b i s(2-c y a n o-3-((2-o x o p r o p y l) t h i o)-3-$ (phenylamino)acrylamide) (11)

General procedure : A solution of compound $2(0.01 \mathrm{~mol})$, in a mixture of EtOH:DMF $(2: 1, v: v)(30 \mathrm{~mL})$, and phenacyl bromide $(4 \mathrm{~g}, 0.02 \mathrm{~mol})$ and/or chloroacetonitrile $(1.4 \mathrm{~g}, 0.02$ $\mathrm{mol})$ and/or chloroacetone $(1.5 \mathrm{~g}, 0.02 \mathrm{~mol})$ was stirred $4-6 \mathrm{~h}$. The reaction mixture was poured onto crushed ice. The obtained solid product was collected by filtration, washed, dried and crystallized from ethanol to give compounds 5, 9 and 11, respectively (Scheme 2 ).

$\left(2 Z, 2^{\prime} Z\right)-N, N^{\prime}-(1,4-p h e n y l e n e) b i s(2-c y a n o-3-((2-o x o-2-p h e n y l$ ethyl)thio)-3-(phenylamino)acrylamide) (5): Color: Yellow powder. Yield: $30 \%$. M.p.: $185^{\circ} \mathrm{C}$. IR $\left(\mathrm{KBr}, v, \mathrm{~cm}^{-1}\right)$ : $3295(\mathrm{NH})$, $2925\left(\mathrm{CH}_{2}\right), 2186(\mathrm{CN}), 1649(\mathrm{CONH}), 1599(\mathrm{C}=\mathrm{C}) .{ }^{1} \mathrm{HNMR}$ (300MHz, DMSO- $\left.d_{6}, \delta, \mathrm{ppm}\right): 3.72(\mathrm{~s}, 2 \mathrm{H}, 2 \mathrm{NHPh}), 4.30(\mathrm{~s}, 4 \mathrm{H}$, $2 \mathrm{CH}_{2}$ ), 7.23-7.62 (m, $\left.20 \mathrm{H}, \mathrm{Ar}-\mathrm{H}\right)$, 7.31-7.45 (dd, $4 \mathrm{H}, \mathrm{Ar}-\mathrm{H} \mathrm{AB}$ system), 9.70 (s, 2H, 2NHCO). 


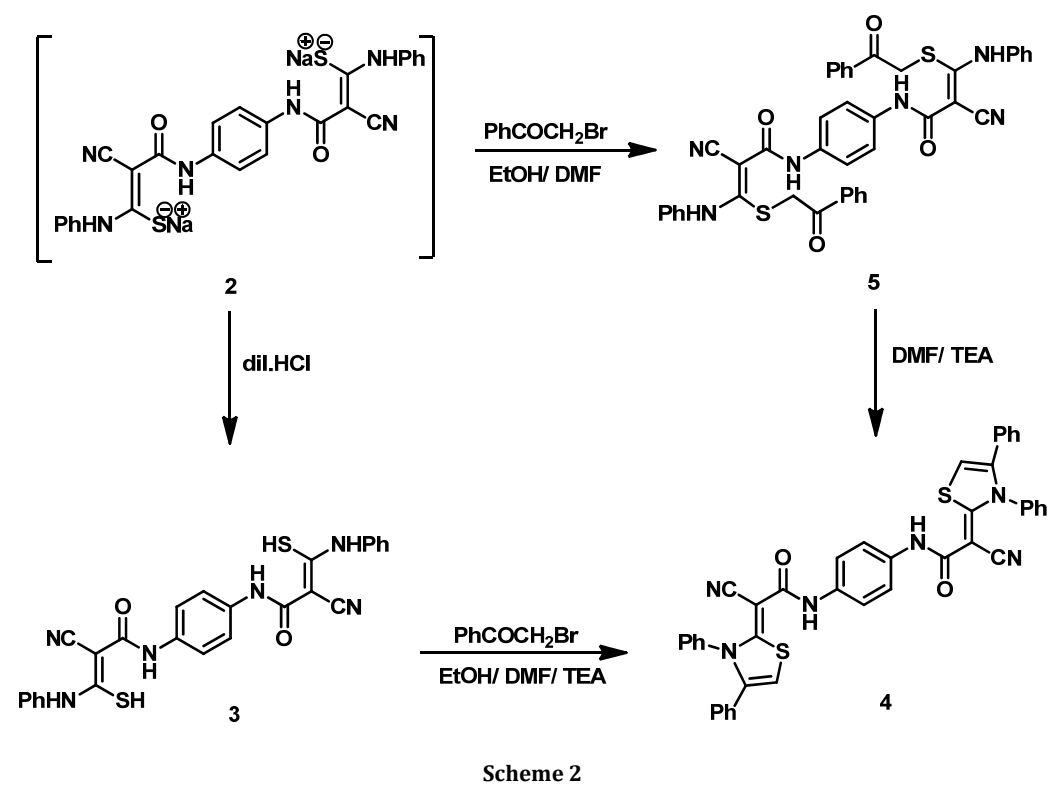

${ }^{13} \mathrm{C}$ NMR $\left(75 \mathrm{MHZ}, \mathrm{DMSO}-d_{6}, \delta, \mathrm{ppm}\right): 192(2 \mathrm{C}, \mathrm{CO}-\mathrm{Ph}), 171$ (2C, C-S), 162 (2C, CO-NH), 136 (4C, Ar-C), 133 (4C, Ar-C), 129 (4C, Ar-C), 126 (4C, Ar-C), 124 (4C, Ar-C), 123 (4C, Ar-C), 122 (2C, Ar-C), 120 (4C, Ar-C), 118 (2C, CN), 71 (2C, C-CN), 38 (2C, $\mathrm{CH}_{2}$-S). LC-MS (m/z): $748\left(\mathrm{M}^{+}, 20\right), 746$ (4) 713 (4), 680 (4), 391 (4), 327 (6), 276 (36), 172 (11), 135 (19), 77 (100). Anal. calcd. for $\mathrm{C}_{42} \mathrm{H}_{32} \mathrm{~N}_{6} \mathrm{O}_{4} \mathrm{~S}_{2}$ (748.19): C, 67.36; $\mathrm{H}, 4.31$; N, 11.22; 0, 8.55; S, 8.56. Found: C, 67.38; H, 4.26; N, 11.24; 0, 8.54; S, $8.58 \%$.

(2Z,2'Z)- $N, N^{\prime}-(1,4-$ phenylene)bis(2-cyano-3-((cyanomethyl) thio)-3-(phenylamino)acrylamide) (9): Color: Yellow powder. Yield: $20 \%$. M.p.: $215^{\circ} \mathrm{C}$. IR (KBr, v, cm-1): 3407 (NH), 2923 $\left(\mathrm{CH}_{2}\right), 2193(\mathrm{CN}), 1656(\mathrm{CONH}), 1606(\mathrm{C}=\mathrm{C}) .{ }^{1} \mathrm{HNMR}(300 \mathrm{MHz}$, DMSO- $\left.d_{6}, \delta, \mathrm{ppm}\right): 4.00(\mathrm{~s}, 2 \mathrm{H}, 2 \mathrm{NHPh}), 4.11\left(\mathrm{~s}, 4 \mathrm{H}, 2 \mathrm{CH}_{2}\right), 7.02-$ 7.71 (m, 14H, Ar-H), 9.70 (s, 2H, 2NHCO). LC-MS (m/z): 590 $\left(\mathrm{M}^{+}, 15\right), 591$ (4), 524 (2), 376 (17), 350 (12), 243 (33), 215 (71), 169 (16), 132 (31), 77 (100). Anal. calcd. for $\mathrm{C}_{30} \mathrm{H}_{22} \mathrm{~N}_{8} \mathrm{O}_{2} \mathrm{~S}_{2}$ (590.13): C, 61.00; H, 3.75; N, 18.97; 0, 5.42; S, 10.86. Found: C, 60.94; H, 3.73; N, 18.99; 0, 5.45; S, 10.89\%.

$\left(2 Z, 2^{\prime} Z\right)-N, N^{\prime}-(1,4-$ phenylene $)$ bis(2-cyano-3-((2-oxopropyl) thio)-3-(phenylamino)acrylamide) (11): Color: Yellow powder. Yield: $60 \%$. M.p.: $154^{\circ} \mathrm{C}$. IR (KBr, v, cm$\left.{ }^{-1}\right): 3279(\mathrm{NH}), 2924$ $\left(\mathrm{CH}_{2}\right), 2184(\mathrm{CN}), 1723\left(\mathrm{COCH}_{3}\right), 1644(\mathrm{CONH}) .{ }^{1} \mathrm{H}$ NMR $(300$ MHz, DMSO- $\left.d_{6}, \delta, \mathrm{ppm}\right): 2.10\left(\mathrm{~s}, 6 \mathrm{H}, 2 \mathrm{CH}_{3}\right), 3.45\left(\mathrm{~s}, 4 \mathrm{H}, 2 \mathrm{CH}_{2}\right)$, $4.00(\mathrm{~s}, 2 \mathrm{H}, 2 \mathrm{NHph}), 7.36-7.59(\mathrm{~m}, 14 \mathrm{H}, \mathrm{Ar}-\mathrm{H}), 9.76(\mathrm{~s}, 2 \mathrm{H}$, 2NHCO). ${ }^{13} \mathrm{C}$ NMR (75 MHZ, DMSO- $\left.d_{6}, \delta, \mathrm{ppm}\right): 200$ (2C, CO$\mathrm{CH}_{3}$ ), 171 (2C, C-S), 161 (2C, CO-NH), 139 (2C, Ar-C), 133 (2C, $\mathrm{Ar}-\mathrm{C}), 129$ (4C, Ar-C), 126 (2C, Ar-C), 124 (2C, Ar-C), 123 (2C, Ar-C), 120 (4C, Ar-C), 118 (2C, CN), 71 (2C, C-CN), 38 (2C, $\mathrm{CH}_{2-}$ S), $26\left(2 \mathrm{C}, \mathrm{CH}_{3}\right)$. LC-MS (m/z): $624\left(\mathrm{M}^{+}, 9\right), 338(9), 277$ (4), 257 (7), 243 (11), 232 (83), 217 (10), 201 (5), 189 (16), 150 (12), 135 (19), 108 (46), 93 (40), 86 (63), 77 (70). Anal. calcd. for $\mathrm{C}_{32} \mathrm{H}_{28} \mathrm{~N}_{6} \mathrm{O}_{4} \mathrm{~S}_{2}$ (623.17): C, 63.54; H, 4.69; N, 11.23; 0, 10.26; S, 10.28. Found: C, $63.45 ; \mathrm{H}, 4.73$; N, $11.25 ; \mathrm{O}, 10.27$; S, 10.30\%.

\subsubsection{Synthesis of diethyl $2,2^{\prime}-\left(\left(\left(1 Z, 1^{\prime} \mathrm{Z}\right)-(1,4-p h e n y l e n e\right.\right.$} bis(azanediyl))bis(2-cyano-3-oxo-1-(phenylamino)prop-1ene-3,1-diyl))bis(sulfanediyl))diacetate (6) and 2,2'-(((1Z, 1'Z)-(1,4-phenylenebis(azanediyl))bis(2-cyano-3-oxo-1(phenylamino)prop-1-ene-3,1-diyl))bis(sulfanediyl))diacetyl chloride (8)

To a solution of compound $2(0.01 \mathrm{~mol})$, in a mixture of EtOH:DMF $(2: 1, v: v)(30 \mathrm{~mL})$, ethyl chloroacetate $(1.75 \mathrm{~mL}, 0.02$ mol) or ethyl bromoacetate $(2.3 \mathrm{~mL}, 0.02 \mathrm{~mol})$ or chloroacetic acid $(1.35 \mathrm{~mL}, 0.02 \mathrm{~mol})$ or chloroacetyl chloride $(1.6 \mathrm{~mL}, 0.02$ mol)was added and stirred for $4 \mathrm{~h}$ at room temperature. The reaction mixture was then poured onto crushed ice. The obtained solid product was collected by filtration, washed, dried and crystallized from ethanol to give compounds $\mathbf{6}$ and $\mathbf{8}$, respectively (Scheme 3).

Diethyl 2,2'-(((1Z,1'Z)-(1,4-phenylenebis(azanediyl))bis(2cyano-3-oxo-1-(phenylamino)prop-1-ene-3,1-diyl))bis(sulfane diyl))diacetate (6): Color: Brown powder. Yield: 90\%. M.p.: 272 ${ }^{\circ} \mathrm{C}$. IR (KBr, v, cm$\left.{ }^{-1}\right): 3401(\mathrm{NHPh}), 3322(\mathrm{NH}), 2200(\mathrm{CN}), 1735$ (COOEt), $1660(\mathrm{CONH}), 1594$ (C=C). ${ }^{1} \mathrm{H}$ NMR $(300 \mathrm{MHz}, \mathrm{DMSO}$ $\left.d_{6}, \delta, \mathrm{ppm}\right): 1.21\left(\mathrm{t}, 6 \mathrm{H}, 2 \mathrm{CH}_{3}\right), 3.92(\mathrm{~s}, 2 \mathrm{H}, 2 \mathrm{NHPh}), 4.00(\mathrm{~s}, 4 \mathrm{H}$, $2 \mathrm{CH}_{2} \mathrm{~S}$ ), 4.18 (q, $\left.4 \mathrm{H}, 2 \mathrm{CH}_{2}\right), 7.06-7.61(\mathrm{~m}, 14 \mathrm{H}, \mathrm{Ar}-\mathrm{H}), 9.69$ (s, 2H, 2NHCO). LC-MS $(\mathrm{m} / \mathrm{z}): 684\left(\mathrm{M}^{+}, 73\right), 682(86), 677(96), 669$ (92), 602 (59), 571 (57), 507 (44), 496 (40), 422 (16), 376 (18), 350 (14), 288 (8), 262 (61) , 242 (20), 215 (76), 190 (44), 169 (9),150 (100), 143 (55), 122 (20), 117 (55), 92 (64), 78 (98), 65(69) , 51 (90). Anal. calcd. for $\mathrm{C}_{34} \mathrm{H}_{32} \mathrm{~N}_{6} \mathrm{O}_{6} \mathrm{~S}_{2}$ (684.18): C, 59.63; H, 4.71; N, 12.27; O, 14.02; S, 9.36. Found: C, 59.59; H, $4.65 ; \mathrm{N}, 12.33 ; 0,14.04 ; \mathrm{S}, 9.38 \%$.

2,2'-(((1Z,1'Z)-(1,4-phenylenebis(azanediyl))bis(2-cyano-3oxo-1-(phenylamino)prop-1-ene-3,1-diyl))bis(sulfanediyl)) diacetyl chloride (8): Color: Orange powder. Yield: 50\%. M.p.: $160{ }^{\circ} \mathrm{C}$. IR (KBr, v, cm-1): $3408(\mathrm{NHPh}), 3318(\mathrm{NH}), 2922\left(\mathrm{CH}_{2}\right)$, 2194 (CN), 1745 (COCl), 1655 (CONH). ${ }^{1} \mathrm{H}$ NMR (300 MHz, DMSO- $\left.d_{6}, \delta, \mathrm{ppm}\right): 3.82(\mathrm{~s}, 2 \mathrm{H}, 2 \mathrm{NHPh}), 4\left(\mathrm{~s}, 4 \mathrm{H}, 2 \mathrm{CH}_{2}\right), 7.20-$ $7.63(\mathrm{~m}, 14 \mathrm{H}, \mathrm{Ar}-\mathrm{H}), 9.55$ (s, 2H, 2NHCO). LC-MS (m/z): 664 $\left(\mathrm{M}^{+}, 23\right), 525(1), 417$ (23), 350 (11), 243 (46), 215 (92), 169 (18), 132 (42), 107 (46), 77 (100). Anal. calcd.f or $\mathrm{C}_{30} \mathrm{H}_{22} \mathrm{~N}_{6} \mathrm{O}_{4} \mathrm{~S}_{2} \mathrm{Cl}_{2}$ (664.05): C, 54.14; H, 3.33; Cl, 10.65; N, 12.63; 0, 9.62; S, 9.64. Found: C, 54.09; H, 3.30; Cl, 10.69; N, 12.65; O, $9.63 ; \mathrm{S}, 9.65 \%$.

2.2.5. Synthesis of $\left(2 \mathrm{z}, 2^{\prime} \mathrm{z}\right)-\mathrm{N}, N^{\prime}-(1,4-$ phenylene)bis(2-cyano2-(4-oxo-3-phenylthiazolidin-2-ylidene)acetamid) (7)

Method A: A solution of compound 3 (5.12 g, $0.01 \mathrm{~mol})$, in a mixture of EtOH:DMF $(2: 1, v: v)(30 \mathrm{~mL})$, and chloroacetyl chloride $(1.6 \mathrm{~mL}, 0.02 \mathrm{~mol})$ and/or ethyl chloroacetate $(1.75$ $\mathrm{mL}, 0.02 \mathrm{~mol})$ and/or ethyl bromoacetate $(2.3 \mathrm{~mL}, 0.02 \mathrm{~mol})$ and/or chloroacetic acid (1.35 mL, $0.02 \mathrm{~mol})$, in the presence of triethylamine (4 drops), was refluxed for $4 \mathrm{~h}$ (Scheme 3). 


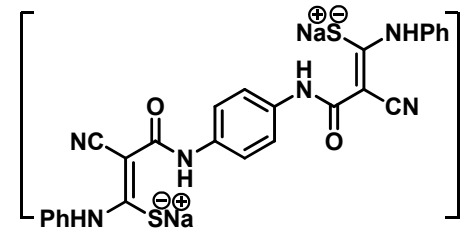

2

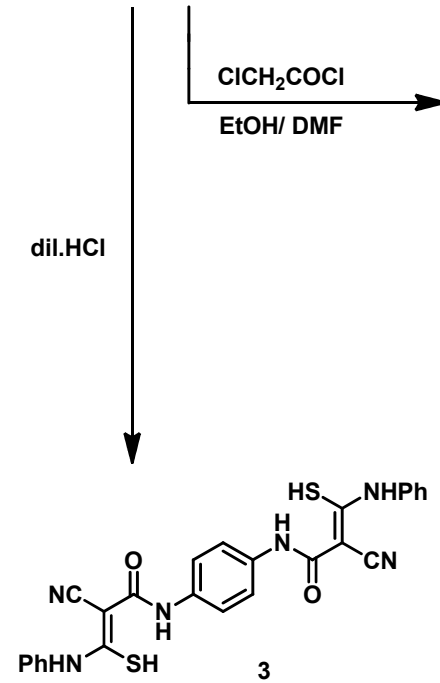

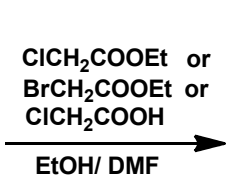<smiles>CCOCCNC(Sc1ccccc1)=C(Nc1ccccc1)C(=O)Nc1ccc(NC(=O)C(C#N)=C(Nc2ccccc2)SCC(=O)OCC)cc1</smiles>

6
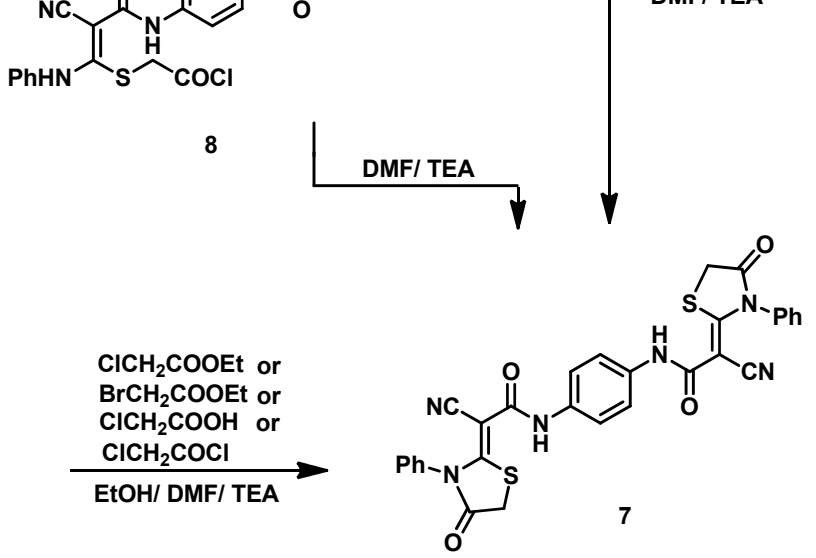

Scheme 3

The reaction mixture was allowed to cool, poured onto crushed ice. The obtained solid product was collected by filtration, washed, dried and crystallized from ethanol to give compound 7.

Method B: A solution of compound 6 or $8(0.01 \mathrm{~mol})$, in DMF (30 $\mathrm{mL})$, in presence of triethylamine (4 drops), was refluxed $4 \mathrm{~h}$. The reaction mixture was poured onto crushed ice. The obtained solid product was collected by filtration, washed, dried and crystallized from ethanol to give compound 7.

$\left(2 z, 2^{\prime} z\right)-N, N^{\prime}$-(1,4-phenylene)bis(2-cyano-2-(4-oxo-3-phenyl thiazolidin-2-ylidene)acetamid) (7): Color: Brown powder. Yield: 90\%. M.p.: $247{ }^{\circ} \mathrm{C}$. IR (KBr, v, cm-1): 3401 (NH), 2194 (CN), 1735 (CO), 1656 (CONH). ${ }^{1} \mathrm{H}$ NMR (300 MHzZ, DMSO-d6, $\delta, \mathrm{ppm}): 3.97\left(\mathrm{~s}, 4 \mathrm{H}, 2 \mathrm{CH}_{2}\right), 7.23-7.55(\mathrm{~m}, 14 \mathrm{H}, \mathrm{Ar}-\mathrm{H}), 9.28(\mathrm{~s}$, 2H, 2NHCO). LC-MS (m/z): $592\left(\mathrm{M}^{+}, 2\right), 458$ (2), 448 (4), 431 (2), 422 (6), 404 (2), 375 (8), 350 (9), 271 (4), 215 (35), 143 (28), 134 (42), 93 (59), 77 (100). Anal. calcd. for $\mathrm{C}_{30} \mathrm{H}_{20} \mathrm{~N}_{6} \mathrm{O}_{4} \mathrm{~S}_{2}$ (592.10): C, 60.80; H, 3.40; N, 14.18; 0, 10.80; S, 10.82. Found: C, 60.74; H, 3.42; N, 14.20; 0, 10.78; S, 10.86\%.

\subsubsection{Synthesis of $(2 Z, 2 ' Z)-N, N$ '-(1,4-phenylene)bis(2-(4-} amino-3-phenylthiazol-2(3H)-ylidene)-2-cyanoacetamide) (10)

Method A: A solution of compound $3(5.12 \mathrm{~g}, 0.01 \mathrm{~mol})$ in a mixture of EtOH:DMF $(2: 1, v: v)(30 \mathrm{~mL})$ containing few drops of triethylamine (4 drops) was treated with chloroacetonitrile $(1.4 \mathrm{~g}, 0.02 \mathrm{~mol})$. The reaction mixture was refluxed for $6 \mathrm{~h}$, and allowed to cool, poured onto crushed ice. The solid product was collected by filtration, washed, dried and crystallized from ethanol to give compound $\mathbf{1 0}$ (Scheme 4).

Method B: A solution of compound 9 (5.9 g, $0.01 \mathrm{~mol})$, in $\operatorname{DMF}(30 \mathrm{~mL})$, in presence of triethylamine (4 drops), wasrefluxed $6 \mathrm{~h}$. The reaction mixture was poured onto crushed ice. The obtained solid product was collected by filtration, washed, dried and crystallized from ethanol to give compound 10.

(2Z, $\left.2^{\prime} Z\right)-N, N^{\prime}$-(1,4-phenylene)bis(2-(4-amino-3-phenyl thiazol-2(3H)-ylidene)-2-cyanoacetamide) (10): Color: Green powder. Yield: $78 \%$. M.p.: $270{ }^{\circ} \mathrm{C}$. IR (KBr, $\left.v, \mathrm{~cm}^{-1}\right): 3399(\mathrm{NH})$, 2197 (CN), 1650 (CO). ${ }^{1} \mathrm{HNMR}\left(300 \mathrm{MHz}, \mathrm{DMSO}-d_{6}, \delta, \mathrm{ppm}\right)$ : 1.21 (s, $\left.4 \mathrm{H}, 2 \mathrm{NH}_{2}\right), 4.11$ (s, $\left.2 \mathrm{H}, 2 \mathrm{CH}\right), 7.02-7.56(\mathrm{~m}, 14 \mathrm{H}, \mathrm{Ar}-\mathrm{H})$, 9.63 (s, 2H, 2NHCO). LM-CS (m/z): $590\left(\mathrm{M}^{+}, 10\right), 538(2), 451$ (24), 374 (17), 348 (18), 266 (10), 215 (13), 174 (11), 134 (59), 127 (12), 77 (100). Anal. calcd. for $\mathrm{C}_{30} \mathrm{H}_{22} \mathrm{~N}_{8} \mathrm{O}_{2} \mathrm{~S}$ (590.13): C, 61.00; H, 3.75; N, 18.97; 0, 5.42; S, 10.86. Found: C, 60.95; H, 3.77 ; N, $18.95 ; 0,5.45 ; \mathrm{S}, 10.88 \%$.

\subsubsection{Synthesis of $N, N^{\prime}-(1,4-p h e n y l e n e) b i s(5-a c e t y l-4-a m i n o-$} 2-(phenylamino)thiophene-3-carboxamide) (12)

Method A: A solution of compound $3(5.12 \mathrm{~g}, 0.01 \mathrm{~mol})$ in a mixture of EtOH:DMF $(2: 1, v: v)(30 \mathrm{~mL})$ containing few drops of triethylamine ( 4 drops) was treated with chloroacetone $(1.5 \mathrm{~g}$, $0.02 \mathrm{~mol})$. The reaction mixture was refluxed for $4 \mathrm{~h}$, allowed to cool, poured onto crushed ice. The solid product was collected by filtration, washed, dried and crystallized from ethanol to give compound $\mathbf{1 2}$ (Scheme 5).

Method B: A solution of compound $11(6.26 \mathrm{~g}, 0.01 \mathrm{~mol})$, in DMF (30 mL), in presence of triethylamine (4 drops), was refluxed $4 \mathrm{~h}$. The reaction mixture was poured onto crushed ice. The obtained solid product was collected by filtration, washed, dried and crystallized from ethanol to give compound 12

$N, N^{\prime}$-(1,4-phenylene)bis(5-acetyl-4-amino-2-(phenylamino) thiophene-3-carboxamide) (12): Color: Brown powder. Yield: 70\%. M.p.: $234{ }^{\circ} \mathrm{C}$. IR (KBr, v, cm-1): 3270 (NH), 2191 (CN), $1743\left(\mathrm{COCH}_{3}\right), 1660(\mathrm{CONH}) .{ }^{1} \mathrm{H}$ NMR $\left(300 \mathrm{MHz}, \mathrm{DMSO}-d_{6}, \delta\right.$, ppm): $2.50\left(\mathrm{~s}, 6 \mathrm{H}, 2 \mathrm{CH}_{3}\right), 7.11\left(\mathrm{~s}, 4 \mathrm{H}, 2 \mathrm{NH}_{2}\right), 7.36-7.63(\mathrm{~m}, 14 \mathrm{H}$, Ar-H), 9.72 (s, 2H, 2NHPh), 9.78 (s, 2H, 2NHCO). 


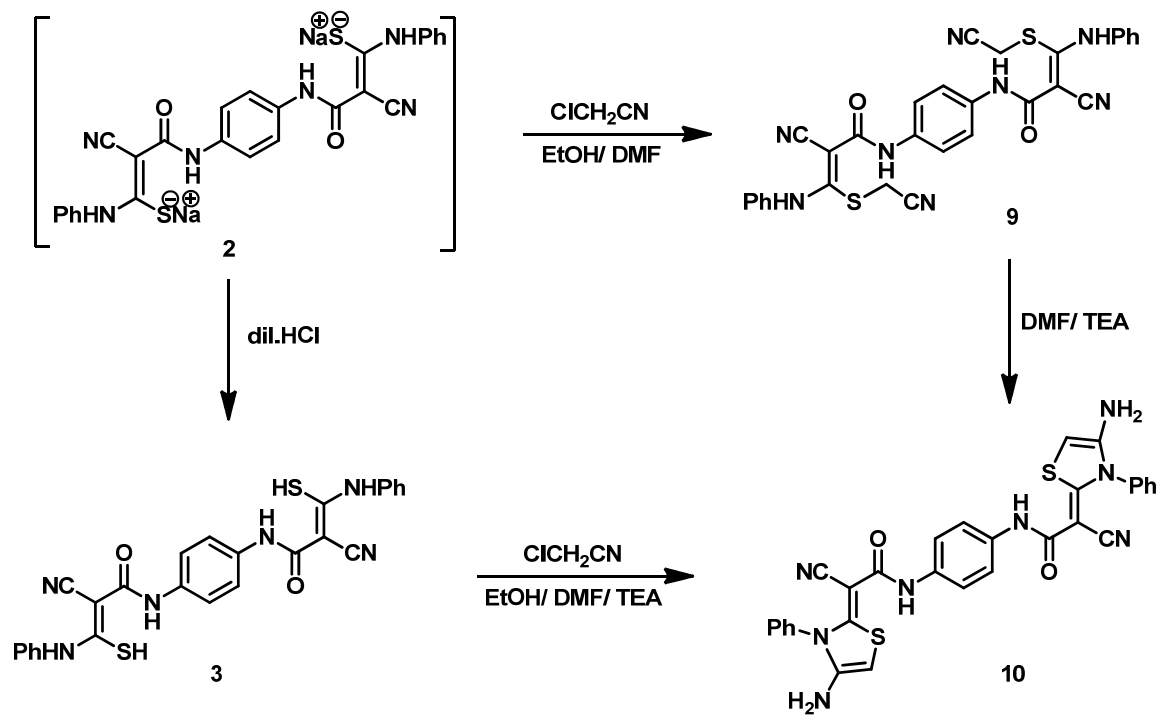

Scheme 4

LM-CS $(\mathrm{m} / \mathrm{z}): 624\left(\mathrm{M}^{+}, 9\right), 376(2), 350(4), 338(9), 277$ (4), 257 (7), 243 (11), 232 (83), 217 (10), 189 (16), 135 (19), 108 (46), 77 (70). Anal. calcd. for $\mathrm{C}_{32} \mathrm{H}_{28} \mathrm{~N}_{6} \mathrm{O}_{4} \mathrm{~S}_{2}$ (624.16): C, 61.52; H, 4.52; N, 13.45; O, 10.24; S, 10.27. Found: C, 61.45; H, 4.54; N, $13.48 ; 0,10.25 ; \mathrm{S}, 10.28 \%$

\subsubsection{Synthesis of $(2 z, 2 ' z)-N, N^{\prime}-(1,4-p h e n y l e n e) b i s(2-c y a n o-$ 3-(methylthio)-3-(phenylamino)acrylamide)derivatives (13a, 13b and 14)}

To a solution of compound 2 ( $0.01 \mathrm{~mol})$, in DMF ( $30 \mathrm{~mL}$ ) in presence of alcoholic $\mathrm{KOH}(10 \%)$ (formed from $0.56 \mathrm{~g} \mathrm{KOH}+$ $100 \mathrm{~mL}$ EtOH), 1,3-dibromopropane (2 mL, $0.02 \mathrm{~mol}$ )or 1,4dibromobutane $(2.2 \mathrm{~mL}, 0.02 \mathrm{~mol})$ or 1,2-bis(bromomethyl) benzene $(2.6 \mathrm{~mL}, 0.02 \mathrm{~mol})$ was added and stirred overnight at room temperature. The reaction mixture was poured onto crushed ice. The obtained solid product was collected by filtration, washed, dried and crystallized from ethanol to give compounds 13a, 13b, 14, respectively (Scheme 6).

(4Z,11Z)-3,13-dioxo-5,11-bis(phenylamino)-6,10-dithia-2,14diaza-1(1,4)-benzenacyclotetradecaphane-4,11-diene-4,12dicarbonitrile (13a): Color: Green powder. Yield: 90\%. M.p.: $170{ }^{\circ} \mathrm{C}$. IR (KBr, v, cm-1): 3303 (NHPh), 3284 (NHCO), 2192 (CN), 1660 (CO). ${ }^{1} \mathrm{H}$ NMR (300 MHz, DMSO- $\left.d_{6}, \delta, p p m\right): 1.72$ $1.93\left(\mathrm{~m}, 2 \mathrm{H}, \mathrm{CH}_{2}\right), 3.40\left(\mathrm{t}, 4 \mathrm{H}, 2 \mathrm{CH}_{2} \mathrm{~S}\right), 3.68(\mathrm{~s}, 2 \mathrm{H}, 2 \mathrm{NHPh})$, 7.21-7.55 (m, 14H, Ar-H), 9.56 (s, 2H, 2NHCO). LM-CS $(\mathrm{m} / \mathrm{z})$ : $552\left(\mathrm{M}^{+}, 40\right), 558$ (20), 333 (25), 214 (25), 160 (33), 143 (29), 125 (37), 106 (37), 99 (29), 93 (83), 79 (41), 76 (79), 60 (100). Anal. calcd. for $\mathrm{C}_{29} \mathrm{H}_{24} \mathrm{~N}_{6} \mathrm{O}_{2} \mathrm{~S}_{2}$ (552.14): $\mathrm{C}, 63.02 ; \mathrm{H}, 4.38$; N, 15.21; 0, 5.79; S, 11.60. Found: C, 62.96; H, 4.36; N, 15.26; O, $5.82 ; \mathrm{S}, 11.60 \%$

(4Z,12Z)-3,14-dioxo-5,12-bis(phenylamino)-6,11-dithia-2,15 diaza-1(1,4)-benzenacyclopentadecaphane-4,12-diene-4,13dicarbonitrile (13b): Color: Green powder. Yield: 89\%. M.p.: $155^{\circ} \mathrm{C}$. IR (KBr, $\left.v, \mathrm{~cm}^{-1}\right): 3280-3330(\mathrm{NH}), 2194(\mathrm{CN}), 1631$ (CO). ${ }^{1} \mathrm{H}$ NMR (300 MHz, DMSO- $\left.d_{6}, \delta, \mathrm{ppm}\right): 1.52-1.75(\mathrm{~m}$ $\left.4 \mathrm{H}, 2 \mathrm{CH}_{2}\right), 3.40\left(\mathrm{t}, 4 \mathrm{H}, 2 \mathrm{CH}_{2} \mathrm{~S}\right), 4.10(\mathrm{~s}, 2 \mathrm{H}, 2 \mathrm{NHPh}), 7.23-7.43$ (m, 14H, Ar-H), $9.41(\mathrm{~s}, 2 \mathrm{H}, 2 \mathrm{NHCO})$. LM-CS $(\mathrm{m} / \mathrm{z}): 566\left(\mathrm{M}^{+}, 18\right)$, 569 (9), 519 (1), 496 (1), 470 (2), 426 (1), 391 (1), 335 (2), 301 (4), 276 (1), 260 (4), 246 (1), 231 (5), 176 (11), 143 (42), 119 (25), 88 (53), 77 (66), 60 (100). Anal. calcd. for $\mathrm{C}_{30} \mathrm{H}_{26} \mathrm{~N}_{6} \mathrm{O}_{2} \mathrm{~S}$ (566.16): C, 63.58; H, 4.62; N, 14.83; 0, 5.65; S, 11.32. Found: C, 63.52; H, 4.64; N, 14.85; 0, 5.66; S, 11.33\%.
(4Z,11Z)-3,13-dioxo-5,11-bis(phenylamino)-6,10-dithia-2,14diaza-1(1,4),8(1,2)-dibenzenacyclotetradecaphane-4,11-diene4,12-dicarbonitrile (14): Color: Green powder. Yield: $91 \%$. M.p.: $197{ }^{\circ} \mathrm{C}$. IR (KBr, v, cm-1): 3401 (NHPh), 3259 (NHCO), 2192 (CN), 1660 (CO). ${ }^{1} \mathrm{H}$ NMR (300 MHz, DMSO- $d_{6}, \delta, \mathrm{ppm}$ ): 3.86 (s, $\left.4 \mathrm{H}, 2 \mathrm{CH}_{2}-\right)$, 7.14-7.40 (m, 14H, Ar-H), 7.60 (d, 4H, Ar-H, AB system), $9.51(\mathrm{~s}, 2 \mathrm{H}, 2 \mathrm{NHPh}), 11.65(\mathrm{~s}, 2 \mathrm{H}, 2 \mathrm{NHCO})$. LM-CS $(\mathrm{m} / \mathrm{z})$ : $614\left(\mathrm{M}^{+}, 7\right), 578(5), 169(24), 141$ (19), 135 (24), 126 (24), 105 (38), 93 (90), 80 (100), 67 (47). Anal. calcd. for $\mathrm{C}_{34} \mathrm{H}_{26} \mathrm{~N}_{6} \mathrm{O}_{2} \mathrm{~S}_{2}$ (614.16): C, 66.43; $\mathrm{H}, 4.26 ; \mathrm{N}, 13.67 ; 0,5.21 ; \mathrm{S}$, 10.43. Found: C, 66.36; H, 4.29; N, 13.69; 0, 5.24; S, $11.42 \%$.

\subsubsection{Synthesis of $\left(2 z, 2^{\prime} z\right)-N, N^{\prime}-(1,4-p h e n y l e n e) b i s(2-c y a n o-$ 3-(2,6-diaminopyrimidin-4-ylthio)-3-(phenylamino) acrylamide) (15)}

To a solution of compound $2(0.01 \mathrm{~mol})$, in a mixture of DMF:acetone $(1: 2, v: v)(30 \mathrm{~mL})$, in presence of potassium carbonate $(1.38 \mathrm{~g}, 0.01 \mathrm{~mol})$, and 6-chloro-2,4-diamino pyrimidine $(3 \mathrm{~mL}, 0.02 \mathrm{~mol})$ was refluxed $5 \mathrm{~h}$. The reaction mixture was allowed to cool, poured onto crushed ice. The obtained solid product was collected by filtration, washed, dried and crystallized from ethanol to give compound $\mathbf{1 5}$ (Scheme 6). Color: Green powder. Yield: $73 \%$. M.p.: $155^{\circ} \mathrm{C}$. IR $\left(\mathrm{KBr}, v, \mathrm{~cm}^{-1}\right): 3397\left(\mathrm{NH}_{2}\right), 3315\left(\mathrm{NH}_{2}\right), 3282(\mathrm{NHPh}), 3195$ (NHCO), 2927 (CH), 2192 (CN), 1644 (CO). ${ }^{1} \mathrm{H}$ NMR (300 MHz, DMSO- $\left.d_{6}, \delta, \mathrm{ppm}\right): 4.10(\mathrm{~s}, 2 \mathrm{H}, 2 \mathrm{NHPh}), 5.86(\mathrm{~s}, 2 \mathrm{H}, 2 \mathrm{CH}-$ pyrimidine), 6.55-6.65 (sb, $\left.8 \mathrm{H}, 4 \mathrm{NH}_{2}\right), 7.02-7.50(\mathrm{~m}, 14 \mathrm{H}, \mathrm{Ar}-$ H), 9.65 (s, 2H, 2NHCO). LM-CS (m/z): $728\left(\mathrm{M}^{+}, 13\right), 724(2)$ 302 (2), 235 (6), 216 (3), 150 (11), 135 (27), 119 (27), 93 (100), 77 (61), 65 (36). Anal. calcd. for $\mathrm{C}_{34} \mathrm{H}_{28} \mathrm{~N}_{14} \mathrm{O}_{2} \mathrm{~S}_{2}$ (728.20):C, 56.03; H, 3.87; N, 26.91; 0, 4.39; S, 8.80. Found: C, $55.93 ; \mathrm{H}, 3.89 ; \mathrm{N}, 26.95 ; \mathrm{O}, 4.41 ; \mathrm{S}, 8.82 \%$

\subsection{Antimicrobial studies}

The disks of Whatman filter paper were prepared with standard size $(5.0 \mathrm{~mm}$ diameter) and kept into $1.0 \mathrm{oz}$ screw capped wide mouthed containers for sterilization. These bottles are kept into hot air oven at temperature of $150{ }^{\circ} \mathrm{C}$. Then, the standard sterilized filter paper disks impregnated with a solution of the test compound in DMF $(1 \mathrm{mg} / \mathrm{mL})$ were placed on nutrient agar plate seeded with the appropriate test organism in triplicates. 

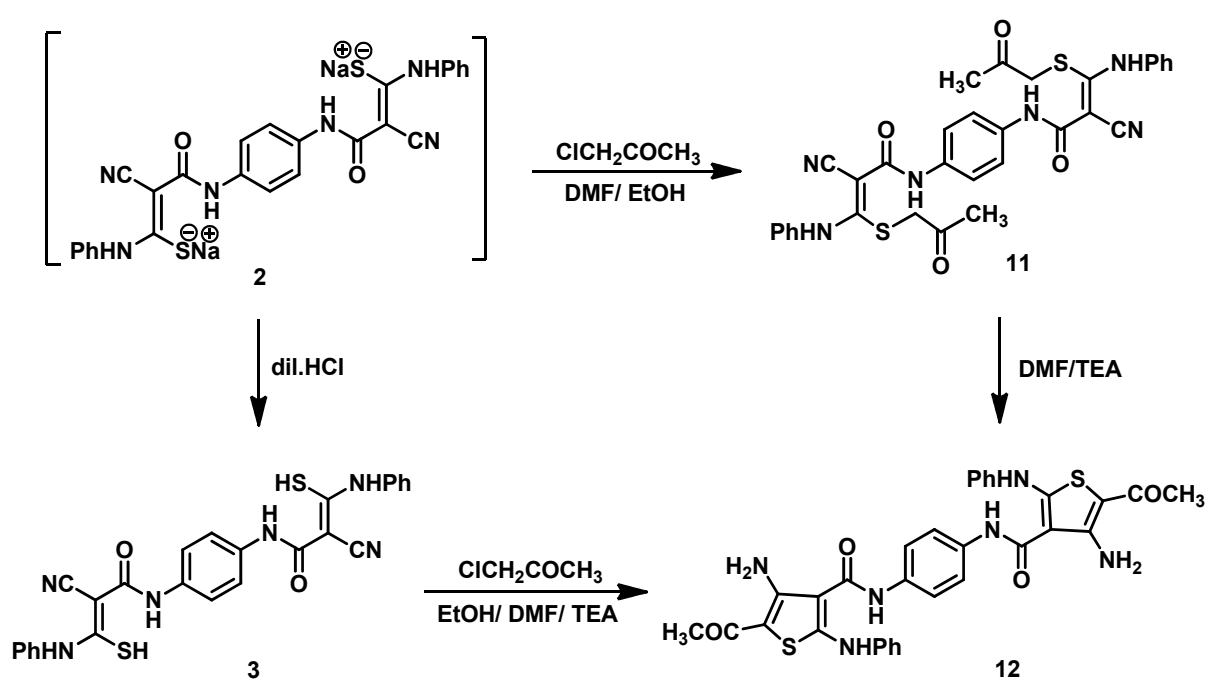

Scheme 5

Standard concentrations of $10^{6} \mathrm{CFU} / \mathrm{mL}$ (Colony Forming $\mathrm{U} / \mathrm{mL}$ ) and $10^{4} \mathrm{CFU} / \mathrm{mL}$ were used for antibacterial and antifungal assay, respectively. Pyrex glass Petri dishes $(9 \mathrm{~cm}$ in diameter) were used and two disks of filter paper were inoculated in each plate. The utilized test organisms were: $B$. subtilis and $B$. thuringiensis as examples of Gram-positive bacteria and E. coli and P. aeruginosa as examples of Gramnegative bacteria. They were also evaluated for their in vitro antifungal potential against $F$. oxysporum and $B$. fabae fungal strains. Chloramphenicol, cephalothin and cycloheximide were used as standard antibacterial and antifungal agents, respectively. DMF alone was used as control at the same abovementioned concentration and due this there was no visible change in bacterial growth. The plates were incubated at $37^{\circ} \mathrm{C}$ for $24 \mathrm{~h}$ for bacteria and for $48 \mathrm{~h}$ for fungi. Compounds that showed significant growth inhibition zones $(>14 \mathrm{~mm})$ using the twofold serial dilution technique, were further evaluated for their minimal inhibitory concentrations (MICs).

\subsection{Minimal inhibitory concentration (MIC) measurement}

The microdilution susceptibility test in Müller-Hinton Broth (Oxoid) and Sabouraud Liquid Medium (Oxoid) were used for the determination of antibacterial and antifungal activity, respectively. Stock solutions of the tested compounds, Chloramphenicol, cephalothin and cycloheximide were prepared in DMF at concentration of $1000 \mathrm{mg} / \mathrm{mL}$. Each stock solution was diluted with standard method broth to prepare serial twofold dilutions in the range of $500-3.125 \mathrm{mg} / \mathrm{mL} 10$ $\mathrm{mL}$ of the broth containing about $10^{6} \mathrm{CFU} / \mathrm{mL}$ of test bacteria was added to each well of 96 -well microtiter plate. The sealed microplates were incubated at $37^{\circ} \mathrm{C}$ for $24 \mathrm{~h}$ for antibacterial activity and at $37{ }^{\circ} \mathrm{C}$ for $48 \mathrm{~h}$ for antifungal activity in a humid chamber. At the end of the incubation period, the minimal inhibitory concentrations (MIC) values were recorded as the lowest concentrations of the substance that had no visible turbidity. Control experiments with DMF and uninoculated media were run parallel to the test compounds under the same conditions. The substance that had no visible turbidity. Control experiments with DMF and uninoculated media were run parallel to the test compounds under the same conditions.

\section{Results and discussion}

In this work, we describe generally applicable extension of this synthetic approach, first was reported by Hantzsch and Weber [23]. Thus, the base catalyzed reaction of the acidic methylene compound $\mathbf{1}$ with phenyl isothiocyanate in $\operatorname{dry} \mathrm{N}, \mathrm{N}$ dimethylformamide at room temperature in basic medium led to the formation of the non- isolable intermediate $\mathbf{2}$ which gave thiocarbamoylderivative3upon treatment with dilute $\mathrm{HCl}$ (Scheme 1).

Assignment of the product $\mathbf{3}$ was based on elemental and spectral analysis. The IR spectrum showed absorption bands at $3403,3291,2185,1593$ and $1233 \mathrm{~cm}^{-1}$ attributable to the $\mathrm{NHPh}$, amidic $\mathrm{NH}, \mathrm{CN}, \mathrm{C}=\mathrm{O}$ and $\mathrm{C}=\mathrm{S}$ functions, respectively. Its ${ }^{1} \mathrm{H}$ NMR spectrum revealed two singlet signals at $\delta 3.84$ and $4.25 \mathrm{ppm}$ for $\mathrm{CH}$ and NHPh protons, multiplet signals at $\delta 7.02$ $7.78 \mathrm{ppm}$ for aromatic protons and singlet signal at $\delta 9.75 \mathrm{ppm}$ for $\mathrm{NH}$ proton.

Compound $\mathbf{3}$ also undergoes cyclization upon the reaction with phenacyl bromide in a mixture of ethanol and $\mathrm{N}, \mathrm{N}$ dimethylformamide (2:1)in presence of catalytic amount of triethylamine yielded a product $\mathbf{4}$, which analyzed correctly for $\mathrm{C}_{42} \mathrm{H}_{28} \mathrm{~N}_{6} \mathrm{O}_{2} \mathrm{~S}_{2}$. The structure 4 was inferred from its correct spectral data. Thus, the IR spectrum showed absorption bands at $3284,2170,1581$ and $1552 \mathrm{~cm}^{-1}$ corresponding to $\mathrm{NH}, \mathrm{CN}$, $\mathrm{CO}$ and $\mathrm{C}=\mathrm{C}$ functions, respectively. Its ${ }^{1} \mathrm{HNMR}$ spectrum revealedsinglet signal at $\delta 6.23 \mathrm{ppm}$ for $\mathrm{CH}$, multiplet signals at $\delta$ 7.23-7.45 ppm for aromatic protons and singlet signal at $\delta$ $9.60 \mathrm{ppm}$ for NH proton. The structure of $\mathbf{4}$ was also confirmed by its mass spectrum which showed the molecular ion peak at $m / z=712\left(\mathrm{M}^{+}, 90 \%\right)$ corresponding to the molecular formula $\mathrm{C}_{42} \mathrm{H}_{28} \mathrm{~N}_{6} \mathrm{O}_{2} \mathrm{~S}_{2}$. Based on the forgoing data, structure 4 was assigned to this product. The structure $\mathbf{4}$ was further confirmed by alternative synthesis. Thus, it was found that, stirring of $\mathbf{2}$ with phenacyl bromide in a mixture of ethanol and $N, N$ dimethylformamide $(2: 1)$ at room temperature afforded the acyclic intermediate $\mathbf{5}$ by $\mathrm{HBr}$ elimination. Structure $\mathbf{5}$ was suggested for the reaction product on the basis of both elemental and spectral analyses. The IR spectrum showed absorption bands at3295, 2186, 1649 and $1599 \mathrm{~cm}^{-}$ ${ }^{1}$ corresponding to $\mathrm{NH}, \mathrm{CN}, \mathrm{CO}$ and $\mathrm{C}=\mathrm{C}$ functions, respectively. Its ${ }^{1} \mathrm{H}-\mathrm{NMR}$ spectrum revealed two singlet signal at $\delta 3.72$ and $4.30 \mathrm{ppm}$ for $\mathrm{NHPh}$ and $\mathrm{CH}_{2}$, multiplet signals at $\delta 7.23-7.62$ ppm for aromatic protons and singlet signal at $\delta 9.70 \mathrm{ppm}$ for $\mathrm{NH}$ proton.

\subsection{Chemistry}




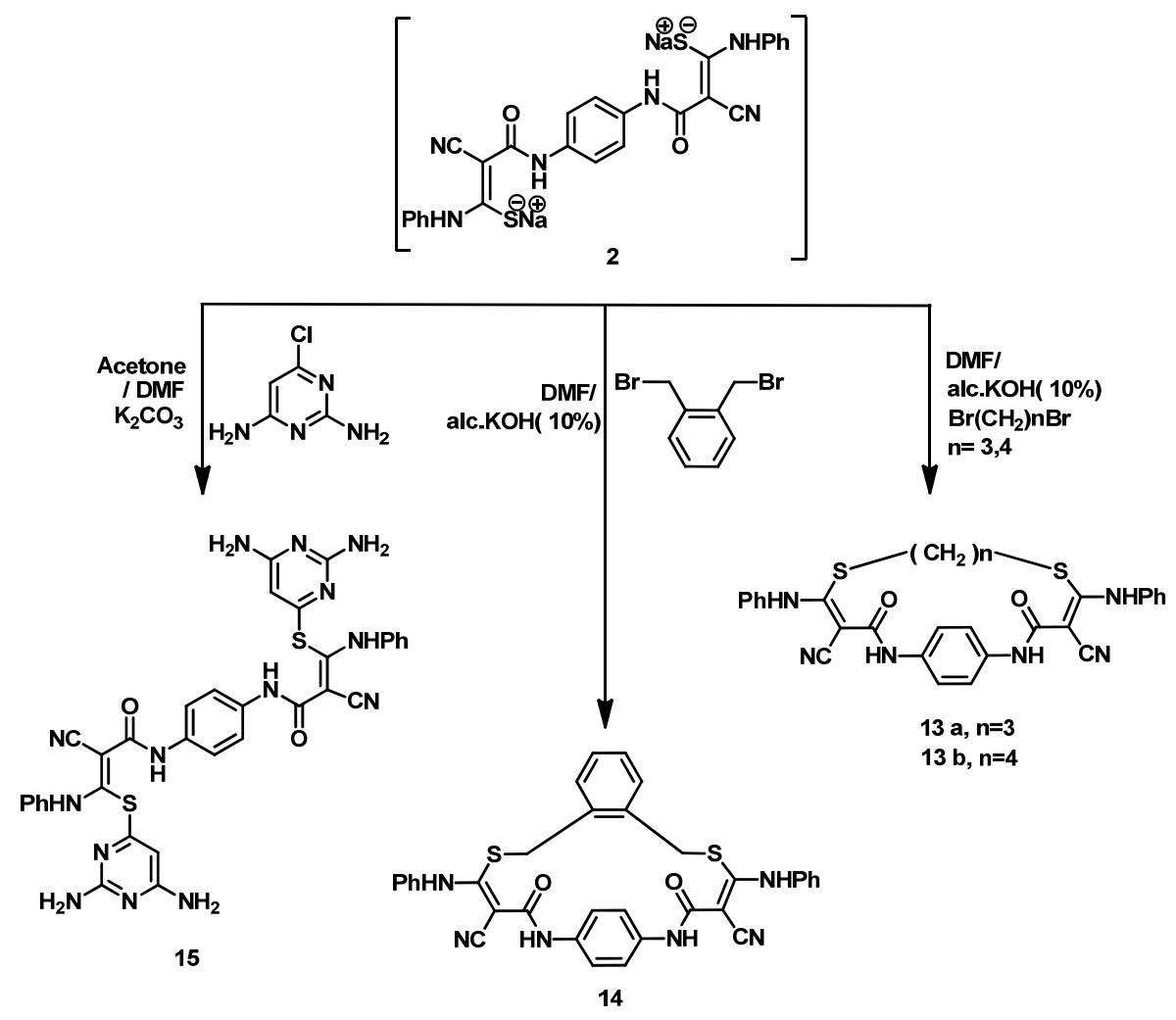

Scheme 6

The structure of compound $\mathbf{5}$ was confirmed also by its mass spectrum which showed a peak at $m / z=746\left(\mathrm{M}^{+-} 2,30 \%\right)$.

Refluxing of compound $\mathbf{5}$ in $N, N$-dimethylformamide with few drops of triethylamineled to the formation of a product identical in all respects (M.p., mixed m.p., IR and ${ }^{1} \mathrm{H}$ NMR) to 4 (Scheme 2).

When the compound $\mathbf{3}$ was treated with ethyl chloroacetate or with ethyl bromoacetate or with chloroacetic acid or with chloroacetyl chloride in a mixture of ethanol and $\mathrm{N}, \mathrm{N}$-dimethylformamide (2:1) with few drops of triethylamine , a product 7 that analyzed for $\mathrm{C}_{30} \mathrm{H}_{20} \mathrm{~N}_{6} \mathrm{O}_{4} \mathrm{~S}_{2}$ was isolated in each case in good yield. While, the reaction of the intermediate $\mathbf{2}$ with ethyl chloroacetate or with ethyl bromoacetate or with chloroacetic acid in mixture of $N, N$-dimethylformamide and ethanol (1:2) led to the formation of compound $\mathbf{6}$. The acyclic structure 6 was established based on its IR spectrum that showed absorption bands at 3401, 3322, 2200, 1735, 1660 and $1594 \mathrm{~cm}^{-1}$ attributable to the NHPh, amidic NH, CN, COOEt, $\mathrm{CONH}$ and $\mathrm{C}=\mathrm{C}$ functions, respectively. Its ${ }^{1} \mathrm{H}$ NMR spectrum revealed triplet signal at $\delta 1.21$ ppm for $\mathrm{CH}_{3}$, two singlet signals at $\delta 3.92$ and $4.00 \mathrm{ppm}$ for $\mathrm{NHPh}$ and $\mathrm{CH}_{2} \mathrm{~S}$, quartet signal at $\delta$ 4.18 ppm for $\mathrm{CH}_{2}$, multiplet signals at $\delta 7.06-7.61 \mathrm{ppm}$ for aromatic protons and singlet signal at $\delta 9.69 \mathrm{ppm}$ amidic $\mathrm{NH}$ protons. Refluxing of $\mathbf{6}$ in $\mathrm{N}, \mathrm{N}$-dimethylformamide and a catalytic amount of triethylamine affordedthe corresponding thiazole derivative 7 . Structure 7 was confirmed on the basis of its elemental and spectral data. The IR spectrum showed bands at $3401,2194,1735$ and $1656 \mathrm{~cm}^{-1}$ attributable to the amidic $\mathrm{NH}, \mathrm{CN}, \mathrm{CO}$ and $\mathrm{CONH}$ functions, respectively. Its ${ }^{1} \mathrm{HNMR}$ spectrum revealed singlet signal at $\delta 3.97$ ppm for $\mathrm{CH}_{2}$ protons, multiplet signals at $\delta 7.23-7.55 \mathrm{ppm}$ for aromatic protons and singlet signal at $\delta 9.28 \mathrm{ppm}$ for $\mathrm{NH}$ proton. The structure of compound 7 was confirmed also by its mass spectrum which showed a peak at $m / z=592\left(\mathrm{M}^{+}, 90 \%\right)$.
The intermediate $\mathbf{2}$ reacted with chloroacetyl chloride in stirring $N, N$-dimethylformamide and ethanol (1:2), a product 8 that analyzed for $\mathrm{C}_{30} \mathrm{H}_{22} \mathrm{~N}_{6} \mathrm{O}_{4} \mathrm{~S}_{2} \mathrm{Cl}_{2}$ was isolated in good yield. The acyclic structure $\mathbf{8}$ was established based on its IR spectrum that showed bands at 3408, 3318, 2194, 1745 and $1655 \mathrm{~cm}^{-1}$ related to $\mathrm{NHPh}, \mathrm{NH}, \mathrm{CN}, \mathrm{COCl}$ and $\mathrm{CONH}$ function groups, respectively. Its ${ }^{1} \mathrm{H}$ NMR spectrum revealed two singlet signals at $\delta 3.82$ and 4.00 ppm for $\mathrm{NHPh}$ and $\mathrm{CH}_{2}$ protons multiplet signals at $\delta 7.20-7.63 \mathrm{ppm}$ for aromatic protons and singlet signal at $\delta 9.55 \mathrm{ppm}$ for amidic $\mathrm{NH}$ proton. The structure of compound $\mathbf{8}$ was confirmed by its mass spectrum which showed a peak at $m / z=664\left(\mathrm{M}^{+}, 50 \%\right)$.

Refluxing of compound $\mathbf{8}$ in $\mathrm{N}, \mathrm{N}$-dimethylformamide and a catalytic amount of triethylamine led to the formation of a product identical in all respects (M.p., mixed m.p., IR and ${ }^{1} \mathrm{H}$ NMR ) to compound 7 (Scheme 3).

Similarly, when the intermediate sodium salt $\mathbf{2}$ is stirred with chloroacetonitrile in a mixture of ethanol and $\mathrm{N}, \mathrm{N}$ dimethylformamide (2:1) at room temperature the correspondding acyclic intermediate $\mathbf{9}$ is exclusively isolated in good yield. The structure of $\mathbf{9}$ has been confirmed on the basis of elemental and spectral data. The IR spectrum exhibits bands at 3407 , 2923, 2193, 1656 and $1606 \mathrm{~cm}^{-1}$ related to the $\mathrm{NHPh}, \mathrm{NH}, \mathrm{CN}$, $\mathrm{CO}$ and $\mathrm{C}=\mathrm{C}$ function groups, respectively. Its ${ }^{1} \mathrm{H}$ NMR spectrum revealed two singlet signals at $\delta 3.90$ and $4.11 \mathrm{ppm}$ corresponding to $\mathrm{NHPh}$ and $\mathrm{CH}_{2}$ protons, multiplet signals at $\delta$ 7.02-7.71 ppm for aromatic protons and singlet signal at $\delta 9.63$ ppm corresponding to amidic NH proton. The correct structure of compound 9 was also confirmed by its mass spectrum which showed a peak at $m / z=591\left(\mathrm{M}^{+}+1,20 \%\right)$. Furthermore, refluxing of the acyclic intermediate 9 in $\mathrm{N}, \mathrm{N}$-dimethyl formamide containing a catalytic amount of triethylamine afforded the thiazole derivative 10. The thiazole derivative $\mathbf{1 0}$ was established based on its IR spectrum which showed bands at 3399, 2197 and $1650 \mathrm{~cm}^{-1}$ related to the amidic $\mathrm{NH}, \mathrm{CN}$ and 
CO function groups, respectively. Its ${ }^{1} \mathrm{H}-\mathrm{NMR}$ spectrum revealed two singlet signals at $\delta 1.21$ and $4.11 \mathrm{ppm}$ forNH $\mathrm{N}_{2}$ and $\mathrm{CH}$ protons, multiplet signals at $\delta 7.02-7.56 \mathrm{ppm}$ for aromatic protons and singlet signal at $\delta 9.76 \mathrm{ppm}$ for $\mathrm{NH}$ proton. The correct structure of compound $\mathbf{1 0}$ was also confirmed by its mass spectrum which showed a peak at $m / z=590\left(\mathrm{M}^{+}, 78 \%\right)$. On the other hand, it has been found that compound $\mathbf{1 0}$ is directly formed by refluxing compound $\mathbf{3}$ with chloroaceto nitrile in a mixture of ethanol and $\mathrm{N}, \mathrm{N}$-dimethylformamide (2:1)and in presence of catalytic amount of triethylamine (Scheme 4).

Stirring of compound 2 with chloroacetone in a mixture of ethanol and $N, N$-dimethylformamide (2:1)at room temperature to afford the acyclic intermediate $\mathbf{1 1}$ by $\mathrm{NaCl}$ elimination. The acyclic intermediate $\mathbf{1 1}$ was established based on its IR spectrum which showed bands at 3279, 2924, 2184, 1723 and $1644 \mathrm{~cm}^{-1}$ corresponding to $\mathrm{NH}, \mathrm{CH}, \mathrm{CN}, \mathrm{COCH}_{3}$ and $\mathrm{CONH}$ function group, respectively. Its ${ }^{1} \mathrm{H}$ NMR spectrum revealed three singlet signals at $\delta 2.10,3.45$ and $4.00 \mathrm{ppm}$ for $\mathrm{CH}_{3}, \mathrm{CH}_{2}$ and NHPh protons, multiplet signals at $\delta 7.36-7.59 \mathrm{ppm}$ for aromatic protons and singlet signal at $\delta 9.70$ foramidic $\mathrm{NH}$ proton. Also, its mass spectrum showed the molecular ion peak at $m / z=624\left(\mathrm{M}^{+}, 60 \%\right)$ corresponding to the molecular formula $\mathrm{C}_{32} \mathrm{H}_{28} \mathrm{~N}_{6} \mathrm{O}_{4} \mathrm{~S}_{2}$.

Refluxing of compound $\mathbf{1 1}$ in $\mathrm{N}, \mathrm{N}$-dimethylformamide in presence of catalytic amount of triethylamine gave the thiophene derivative $\mathbf{1 2}$ whose structure was confirmed by its alternative synthesis. Thus, refluxing of compound $\mathbf{3}$ with chloroacetone in a mixture of ethanol and $N, N$-dimethyl formamide $(2: 1)$ in presence of catalytic amount of triethylamine afforded the thiophene derivative $\mathbf{1 2}$ in reasonably good yield. The structure $\mathbf{1 2}$ was established based on its IR spectrum that showed bands at 3270, 2191, 1743 and $1660 \mathrm{~cm}^{-1}$ related to $\mathrm{NH}, \mathrm{CN}, \mathrm{COCH}_{3}$ and $\mathrm{CONH}$ function groups, respectively. The ${ }^{1} \mathrm{H}$ NMR spectrum of the thiophene derivative 12 revealed two singlet signals at $\delta 2.50$ and7.11 ppm for $\mathrm{CH}_{3}$ and $\mathrm{NH}_{2}$ protons, multiplet signals at $\delta 7.36-7.63 \mathrm{ppm}$ and two singlet signals at $\delta 9.72$ and $9.78 \mathrm{ppm}$ for $\mathrm{PhNH}$ and amidic $\mathrm{NH}$ protons. Also, its mass spectrum showed the molecular ion peak at $m / z=624\left(\mathrm{M}^{+}, 70 \%\right)$ corresponding to the molecular formula $\mathrm{C}_{32} \mathrm{H}_{28} \mathrm{~N}_{6} \mathrm{O}_{4} \mathrm{~S}_{2}$ (Scheme 5).

When the intermediate sodium salt 2 stirred with 1,3dibromopropane in $N, N$-dimethylformamide at room temperature in alcoholic potassium hydroxide, a product 13a that analyzed for $\mathrm{C}_{29} \mathrm{H}_{24} \mathrm{~N}_{6} \mathrm{O}_{2} \mathrm{~S}_{2}$ was isolated in good yield. The structure 13a was established based on its IR spectrum that showed bands at 3303, 3284, 2925, 2192 and $1660 \mathrm{~cm}^{-1}$ corresponding to $\mathrm{NHPh}$, amidic $\mathrm{NH}, \mathrm{CH}_{2}, \mathrm{CN}$ and $\mathrm{CO}$ function groups, respectively. Its ${ }^{1} \mathrm{H}$ NMR spectrum revealed multiplet signals at $\delta 1.72-1.93 \mathrm{ppm}$ attributable to $\mathrm{CH}_{2}$ protons, triplet signal at $\delta 3.40 \mathrm{ppm}$ for $\mathrm{CH}_{2} \mathrm{~S}$ protons, singlet signal at $\delta 3.68$ ppm for NHPh proton, multiplet signals at $\delta 7.21-7.55 \mathrm{ppm}$ for aromatic protons and singlet signal at $\delta 9.56 \mathrm{ppm}$ foramidic $\mathrm{NH}$ proton. The structure of compound 13a was confirmed by its mass spectrum which showed a peak at $m / z=558\left(\mathrm{M}^{+}+6\right.$, 90\%).

Similary, when the intermediate 2 was stirred with 1,4dibromobutane in $\mathrm{N}, \mathrm{N}$-dimethylformamide at room temperature in alcoholic potassium hydroxide, a product $\mathbf{1 3 b}$ that analyzed for $\mathrm{C}_{30} \mathrm{H}_{26} \mathrm{~N}_{6} \mathrm{O}_{2} \mathrm{~S}_{2}$ was isolated in good yield. The structure 13b was established based on its IR spectrum that showed bands at 3280,2927, 2194 and $1631 \mathrm{~cm}^{-1}$ related to $\mathrm{NH}, \mathrm{CH}_{2}, \mathrm{CN}$ and $\mathrm{CO}$ function groups, respectively. Its ${ }^{1} \mathrm{H}$ NMR spectrum revealed multiplet signals at $\delta \quad 1.52-1.75 \mathrm{ppm}$ attributable to $\mathrm{CH}_{2}$ protons, triplet signal at $\delta 3.40 \mathrm{ppm}$ for $\mathrm{CH}_{2} \mathrm{~S}$ protons, singlet signal at $\delta 4.10 \mathrm{ppm}$ for NHPh proton, multiplet signals at $\delta 7.23-7.43 \mathrm{ppm}$ for aromatic protons and singlet signal at $\delta 9.41 \mathrm{ppm}$ foramidic $\mathrm{NH}$ proton. The structure of compound 13b was confirmed by its mass spectrum which showed a peak at $m / z=569\left(\mathrm{M}^{+}+3,89 \%\right)$.
Moreover, the intermediate 2 when reacted with 1,2bis(bromomethyl)benzene in stirring $N, N$-dimethylformamide at room temperature in alcoholic potassium hydroxide, a product 14 that analyzed for $\mathrm{C}_{34} \mathrm{H}_{26} \mathrm{~N}_{6} \mathrm{O}_{2} \mathrm{~S}_{2}$ was isolated in good yield. The structure 14 was established based on its IR spectrum that showed bands at 3401,3259, 2925, 2192 and $1660 \mathrm{~cm}^{-1}$ due to $\mathrm{NHPh}$, amidic $\mathrm{NH}, \mathrm{CH}_{2}, \mathrm{CN}$ and $\mathrm{CO}$ function groups, respectively. Its ${ }^{1} \mathrm{H}$ NMR spectrum revealed a singlet signal at $\delta 3.86 \mathrm{ppm}$ attributable to $\mathrm{CH}_{2} \mathrm{~S}$ protons, multiplet signals at $\delta$ 7.14-7.40 ppm for aromatic protons and two singlet signal at $\delta 9.51$ and $11.65 \mathrm{ppm}$ for NHPh, amidic NH protons. Its mass spectrum showed a peak at $m / z=614\left(\mathrm{M}^{+}, 91 \%\right)$.

In addition to that mentioned above, refluxing the intermediate $\mathbf{2}$ with 6-chloro-2,4-diamino pyrimidine in a mixture of $N, N$-dimethylformamide and acetone $(1: 2)$ in presence of potassium carbonate yielded a product 15, which analyzed correctly for $\mathrm{C}_{34} \mathrm{H}_{28} \mathrm{~N}_{14} \mathrm{O}_{2} \mathrm{~S}_{2}$. The structure $\mathbf{1 5}$ was inferred from its spectral data. Thus, IR spectrum showed absorption bands at 3397, 3315, 3282, 3195, 2192 and 1644 $\mathrm{cm}^{-1}$ corresponding to two $\mathrm{NH}_{2}, \mathrm{NHPh}$ amidic $\mathrm{NH}, \mathrm{CN}$ and $\mathrm{CO}$ functions, respectively. Its mass spectrum showed a peak at $m / z=724\left(\mathrm{M}^{+}-4,73 \%\right)$ (Scheme 6).

\subsection{Antimicrobial activity}

Fifteen of newly synthesized target compounds were evaluated for their in vitro antibacterial activity against Bacillus subtilis and Bacillus thuringiensis as example of Gram-positive bacteria and Escherichia coli and pseudomonas aeruginosa as examples of Gram-negative bacteria. They were also evaluated for their in vitro antifungal potential against Fusarium oxysporum and Botrytis fabae fungal strains.

Agar-diffusion method was used for the determination of the preliminary antibacterial and antifungal activity. Chloramphenicol, cephalothin and cycloheximide were used as reference drugs. The results were recorded for each tested compound as the average diameter of inhibition zones (IZ) of bacterial or fungal growth around the disks in $\mathrm{mm}$. The minimum inhibitory concentration (MIN) measurement was determined for compounds showed significant growth inhibition zones $(>14 \mathrm{~mm})$ using two fold serial dilution method [24]. The MIC $(\mu \mathrm{g} / \mathrm{mL})$ and inhibition zone diameters values are recorded in Table 1.

The results depicted in Table 1 revealed that the most of tested compounds displayed variable inhibitory effects on the growth of the tested Gram-positive and Gram-negative bacterial strains, and also against antifungal strain. In general most of the tested compounds revealed better activity against the Gram-positive rather than the Gram-negative bacteria.

Regarding the structure-activity relationship of the thiazoles derivatives against Gram-positive bacteria, the results revealed that compounds 4, 7, 14 and 15 exhibited broad spectrum antibacterial profile against the tested organisms. Thiazoles derivatives $\mathbf{4}$ and $\mathbf{7}$ recorded higher activity than thiophene derivative 12. In this view, compounds 4, 7, 14, and 15 were equipotent to chloramphenicol in inhibiting the growth of $B$. subtilis (MIC $3.125 \mu \mathrm{g} / \mathrm{mL}$ ), while its activity was $50 \%$ lower than of chloramphenicol against $B$. thuringiensis. Compound 12 showed $50 \%$ of the activity of chloramphenicol (MIC $6.25 \mu \mathrm{g} / \mathrm{mL}$ ) but it was equipotent to cephalothin in inhibiting the growth of $B$. subtilis and B. thuringiensis (MIC $6.25 \mu \mathrm{g} / \mathrm{mL}$ ). On the other hand, compounds $\mathbf{1}, \mathbf{3}, \mathbf{5}, \mathbf{6}, \mathbf{8}, \mathbf{9 , 1 1}$ 13a and 13b exhibited moderate growth inhibitory activity against Gram-positive bacteria as revealed from their MIC values $(6.25-50 \mu \mathrm{g} / \mathrm{mL})$. Among these compounds 13a and 13b showed good growth inhibitory against B. subtilis (MIC 6.25 $\mu \mathrm{g} / \mathrm{mL}$ ), while compounds 5, 6, 8, 9 and 11 showed relatively good growth inhibitory profiles against $B$. subtilis (MIC 12.5 $\mu \mathrm{g} / \mathrm{mL}$ ) which were about $25 \%$ of the activity chloramphenicol and $50 \%$ cephalothin against the same organism. 
Table 1. Minimal inhibitory concentration (MIC, $\mu \mathrm{g} / \mathrm{mL}$ ) and inhibition zone (mm) of some new synthesized compounds *.

\begin{tabular}{|c|c|c|c|c|c|c|}
\hline \multirow[t]{4}{*}{ Compound no } & \multicolumn{6}{|c|}{ MIC in $\mu \mathrm{g} / \mathrm{mL}$, and inhibition (mm) } \\
\hline & \multicolumn{4}{|c|}{ Bacteria } & \multirow{2}{*}{\multicolumn{2}{|c|}{ Fungi }} \\
\hline & \multicolumn{2}{|c|}{ Gram-positive bacteria } & \multicolumn{2}{|c|}{ Gram-negative bacteria } & & \\
\hline & B. subtilis & B. thuringiensis & E. coli & P. aeruginosa & F. oxysporum & B. fabae \\
\hline 1 & $50(18)$ & $50(14)$ & $100(15)$ & $50(19)$ & $100(16)$ & $50(18)$ \\
\hline 3 & $25(27)$ & $50(15)$ & $100(15)$ & $100(16)$ & 50 (19) & $100(16)$ \\
\hline 4 & $3.125(45)$ & $6.25(38)$ & $25(25)$ & $12.5(33)$ & $100(16)$ & $25(27)$ \\
\hline 5 & $12.5(33)$ & $50(14)$ & $50(20)$ & $50(19)$ & $12.5(33)$ & $50(20)$ \\
\hline 6 & $12.5(32)$ & $50(20)$ & $100(15)$ & $100(15)$ & $25(25)$ & $100(16)$ \\
\hline 7 & $3.125(44)$ & $6.25(37)$ & $100(14)$ & $50(20)$ & $6.25(38)$ & $6.25(19)$ \\
\hline 8 & $12.5(32)$ & $50(20)$ & $100(15)$ & $100(15)$ & $25(25)$ & $100(16)$ \\
\hline 9 & $12.5(32)$ & $50(15)$ & $100(15)$ & $100(16)$ & $50(19)$ & $50(20)$ \\
\hline 10 & $6.25(38)$ & $6.25(30)$ & $100(14)$ & $100(15)$ & $100(16)$ & $100(16)$ \\
\hline 11 & $12.5(32)$ & $6.25(38)$ & $100(15)$ & 50 (19) & $100(15)$ & $100(15)$ \\
\hline 12 & $6.25(37)$ & $6.25(37)$ & $100(15)$ & $100(15)$ & $12.5(33)$ & $12.5(32)$ \\
\hline $13 a$ & $6.25(38)$ & $6.25(37)$ & $100(15)$ & 50 (19) & $100(15)$ & $100(16)$ \\
\hline $13 \mathrm{~b}$ & $6.25(38)$ & $6.25(37)$ & $100(15)$ & 50 (19) & $100(15)$ & $100(16)$ \\
\hline 14 & $3.125(40)$ & $6.25(37)$ & $100(15)$ & 50 (19) & $100(15)$ & $100(16)$ \\
\hline 15 & $3.125(41)$ & $6.25(38)$ & $100(15)$ & 50 (19) & $100(15)$ & $100(16)$ \\
\hline Chloramphenicol & $3.125(44)$ & $3.125(44)$ & $6.25(37)$ & $6.25(38)$ & NT & NT \\
\hline Cephalothin & $6.25(36)$ & $6.25(37)$ & $6.25(38)$ & $6.25(37)$ & NT & NT \\
\hline Cycloheximide & NT & NT & NT & NT & $3.125(43)$ & $3.125(42)$ \\
\hline
\end{tabular}

${ }^{*}$ MIC: Minimal inhibitory concentration values with SEM $=0.02$ (The lowest concentration that inhibited the bacterial growth); NT: Not tested.

Concerning the antibacterial activity of the compound $\mathbf{5}$ revealed weak growth inhibitory against the tested Gramnegative bacteria (MIC $50 \mu \mathrm{g} / \mathrm{mL}$ ).

Regarding the activity of thiazole derivatives, against antifungal strains, the results revealed that compound $\mathbf{7}$ was $50 \%$ lower than cycloheximidein inhibitory the growth of $B$. fabae and F. oxysporum (MIC $6.25 \mu \mathrm{g} / \mathrm{mL}$ ), while the activity of compound $\mathbf{5}$ and $\mathbf{1 2}$ were 25\% lower than cycloheximide against $F$. oxysporum (MIC $12.5 \mu \mathrm{g} / \mathrm{mL}$ ).

The substituted pattern was also crucial. It is worth mentioning that formation of cyclic bisulphide and thiazole derivatives produced a high antimicrobial activity. On the other hand, conversion of thiocarbamoyl derivative $\mathbf{3}$ to 5, 6, 8, 9 and 11 unfortunately produced weak antimicrobial activity.

The tested compounds were more active against Grampositive than Gram-negative bacteria, it may be concluded that the antimicrobial activity of the compounds is related to cell wall structure of the bacteria. It is possible because the cell wall is essential to survival of bacteria and some antibiotics are able to kill bacteria by inhibiting a step in the synthesis of peptidoglycan. Gram-positive bacteria possess a thick cell wall containing many layers of peptidoglycan and teichoic acids, but in contrast, Gram-negative bacteria have a relatively thin cell wall consisting of a few layers of peptidoglycan surrounded by a second lipid membrane containing lipopolysaccharides and lipoproteins. These differences in cell wall structure can produce differences in antibacterial susceptibility and some antibiotics can kill only Gram-positive bacteria and are inactive against Gram-negative pathogens [25].

\section{Conclusion}

The present study describes the synthesis and investigates the antimicrobial activities of some new functionalized thiazoles, thiophene and cyclic dithio derivatives with the hope of discovering new structure leads serving as antimicrobial agents.

\section{Acknowledgements}

This study was supported by Chemistry Department, Faculty of Science, Mansoura University, Egypt.

\section{Supplementary materials}

IR, ${ }^{1} \mathrm{H}$ NMR, ${ }^{13} \mathrm{C}$ NMR, LC-MS data for compounds 3-15. This material is available free of charge via the internet at http://www.eurjchem.com.

\section{References}

[1]. Mukerjee, A. K.; Ashare, R. Chem. Rev. 1991, 91, 1-24.

[2]. Ead, H. A.; Abdellah, S. O.; Kassab, N. A.; Metwalli, N. H.; Saleh, H. Arch Pharm. (Weinheim) 1997, 320, 1227-1232.

[3]. Misra, N. C.; Patnaik, K. K.; Indian J. Appl. Chem. 1971, 34, 148-155.

[4]. Rao, R. B.; Singh, S. R. J. IndianChem. Soc. 1973, 50, 492-498.

[5]. Parmer, S. S.; Chaudhari, D. A.; Gupta, T. K. J. Med. Chem. 1972, 15, 99 101.

[6]. Pavlenko, A. F.; Moshchitiskii, S. D. Chem. Heterocyc. Compd. 3; 1968. Chem. Abst. 1967, 68, 114479.

[7]. Tisler, M.; Andolsek, A.; Stanovnik, B.; Likar, M.; Schauer, P. J. Med. Chem. 1971, 14, 53-54.

[8]. Singh, S. R. J. Indian Chem. Soc. 1975, 52, 734-741.

[9]. Chaudhary, H. S.; Pujari, H. K. Indian J. Chem. 1972, 10, 766-771.

[10]. Dhal, P. N.; Achary, T. E.; Nayak, A. Indian J. Chem. 1975, 13, 46-52.

[11]. Mallick, S. K.; Martin, A. R.; Lingard, R. G. J. Med. Chem. 1971, 14, 528532.

[12]. Burton, W. H.; Budde, W. L.; Cheng, J. J. Med. Chem. 1970, 13, 10091012

[13]. Fadda, A. A.; Refat, M. H.; Zaki, M. E. A. Molecules 1999, 5, 701-709.

[14]. Fadda, A. A.; Metwally, M. A.; Bondock, S. B.; El-Desoky, S. I.; Etman, H. A. Sulfur Lett. 2002, 25, 199-205.

[15]. Fadda, A. A.; Metwally, M. A.; Bondock, S. B.; El-Desoky, S. I.; Etman, H. A. Sulfur Lett. 2003, 26, 127-135.

[16]. Bondock, S.; Fadda, A. A. Eur. J. Med. Chem. 2011, 46(6), 2555-2561

[17]. Bondock, S.; Fadaly, W.; Metwally, M. A. Eur. J. Med. Chem. 2010, 45(9), 3692-701

[18]. Fadda, A. A.; Etman, H. A.; Sarhan, A. A.; El-Hadidy, S. A. Phosphorus Sulfur 2010, 185, 526-536.

[19]. El-Shafei, A.; Fadda, A. A.; Khalil, A. M.; Ameen, T. A. E.; Badria, F. A. Bioorg. Med. Chem. 2009, 17, 5096-5105.

[20]. Fadda, A. A.; Abdel-Latif, E.; El-Mekawy, R. E. Phosphorus Sulfur 2008, 183, 1940-1953

[21]. Fadda, A. A.; Abdel-Latif, E.; El-Mekawy, R. E. Pharmacol. Pharm. 2012 $3,148-157$.

[22]. Fadda, A. A.; Abdel-Latif, E.; El-Mekawy, R. E. Eur. J. Med. Chem. 2009 $44,1250-1256$.

[23]. Hantzsch, A.; Weber, H. Chem. Ber. 1887, 20, 3118-3132.

[24]. Fadda, A. A.; Afsah, E. S. M.; Awad, R. S. Eur. J. Med. Chem. 2013, 60, 421-430.

[25]. Abou-Melha, H.; Fadda, A. A. Spectrochim. Acta A 2012, 89, 123-128. 